\title{
Peranan Majelis Taklim dalam Meningkatkan Pemahaman Keagamaan Masyarakat
}

\author{
Saeful Lukman ${ }^{1 *}$, Yusuf Zaenal Abidin ${ }^{1}$, Asep Shodiqin ${ }^{2}$ \\ ${ }^{1}$ Jurusan Manajemen Dakwah, Fakultas Dakwah dan Komunikasi, UIN Sunan Gunung Djati, \\ Bandung \\ ${ }^{2}$ Jurusan Komunikasi Penyiaran Islam, Fakultas Dakwah dan Komunikasi, UIN Sunan Gunung \\ Djati, Bandung \\ *Email:efulgunners@gmail.com
}

\begin{abstract}
ABSTRAK
Tujuan dari penelitian ini untuk mengetahui pemahaman tentang keagamaan masyarakat di lingkungan rw 03 desa Kebonjati. Secara lebih terperinci penelitian ini bertujuan untuk mengetahui materi yang disampaikan oleh da'i, metode yang menjadi pijakan dalam pelaksanaannya, dan untuk mengetahui hasil yang diperoleh mad'u dalam mengikuti kegiatan majelis taklim tersebut. Metode penelitian yang digunakan dalam penelitian ini adalah metode kualitatif deskriptif. Hal ini untuk mengetahui secara jelas mengenai gambaran tentang pemahaman pemikiran yang akan terjadi di masa yang akan datang yaitu mengenai peranan Majelis Taklim At-Taubah dalam meningkatkan pemahaman keagamaan dan pola perilaku masyarakat yang berada di lingkungan desa Kebonjati Sumedang. Hasil penelitian yang dilakukan terhadap majelis taklim At-Taubah dapat diketahui bahwa majelis taklim berperan sebagai lembaga non formal yang berada ditengah-tengah masyarakat memberikan kontribusi yang cukup besar bagi perkembangan pemahaman keagamaan pada masyarakat desa Kebonjati. Hal tersebut terlihat dari adanya perubahan baik dari sikap maupun perilaku masyarakatnya yang semakin agamis.
\end{abstract}

Kata Kunci : Peranan; Majelis Taklim; Pemahaman Keagamaan

\section{ABSTRACT}

The purpose of this study was to determine the understanding of the religious community in $\mathrm{RW} 03$ Kebonjati village. In more detail this research aims to find out the material presented by the da'i, the method that becomes the basis for its implementation, and to find out the results obtained by mad'u in participating in the taklim assembly activities. The research method used in this research is descriptive qualitative method. This is to find out clearly about the description of the understanding of thoughts that will occur in the future, namely the role of 
the Majelis Taklim At-Taubah in improving religious understanding and patterns of behavior of the people in the village of Kebonjati, Sumedang. The results of the research carried out on the At-Taubah taklim assembly can be seen that the taklim assembly acting as a non-formal institution in the midst of the community contributed significantly to the development of religious understanding in the Kebonjati village community. This can be seen from the changes in both the attitude and behavior of the people who are increasingly religious.

Keywords : Role; Majelis Taklim; Religious Understanding

\section{PENDAHULUAN}

Dakwah merupakan kewajiban seluruh umat manusia yang ada di muka bumi ini untuk menyampaikan ayat-ayat Allah. Dakwah adalah mengajak manusia kepada jalan Allah Swt. (system Islam) secara menyeluruh. Dakwah bisa dilakukan baik dengan lisan, tulisan, maupun dengan perbuatan. Hal ini sebagai ikhtiar (upaya) muslim dalam mewujudkan nilai-nilai ajaran Islam dalam realitas kehidupan (Enjang dan Aliyudin, 2009:5).

Pendapat Syekh Ali Mahfudz, dakwah adalah mengajak manusia untuk mengerjakan kebaikan dan mengikuti petunjuk, menyuruh mereka berbuat baik dan melarang mereka dari perbuatan jelek agar mereka mendapat kebahagiaan di dunia dan akhirat. Dengan mengikuti jalan yang telah ditunjukkan oleh Allah Swt. yang telah ditetapkan dalam Al-qur'an dan As-sunnah (Munir, 2003:7).

Dakwah sebagai usaha untuk meningkatkan pemahaman tentang keagamaan guna dapat mengubah pandangan hidup manusia. Sikap bathin dan juga perilaku manusia yang melenceng agar kembali kepada jalan yang benar. Menyadarkan manusia bahwa hukum Allah itu ada dan pasti terjadi. Dimana manusia akan dimintai pertanggungjawaban atas segala perbuatan yang telah dilakukannya. Kehadiran agama Islam yang dibawa Nabi Muhammad Saw diyakini dapat menjamin terwujudnya kehidupan manusia yang sejahtera lahir dan batin. Di dalamnya terdapat berbagai petunjuk tentang bagaimana seharusnya manusia itu menyikapi hidup dan kehidupan ini secara lebih bermakna dalam arti yang seluas-luasnya.

Agama merupakan gejala yang begitu sering terdapat dimana-mana sehingga sedikit membantu usaha-usaha untuk membuat abstraksi ilmiah. Agama berkaitan dengan usaha-usaha manusia untu mengukur dalamnya makna dari keberadaan sendiri dan keberadaan alam semesta. Agama telah menimbulkan khayalan yang pailing luas dan juga digunakan untuk membenarkan kekejaman orang yang luar biasa terhadap orang lain. Agama dapat membangkitkan kebahagian batin yang paing sempuna, dan juga perasaan takut dan ngeri (Nottingham, 1996:4).

Menurut Harun Nasution agama dari segi bahasa dalam masyarakat Indonesia berasal dari kata agama, yaitu din yang berasal dari bahasa Arab dan kata religi yang berasal dari bahasa Eropa. Agama juga berasal dari kata Sankrit. 
Menurut satu pendapat juga, kata agama ini berasal dari kata a yang mempunyai makna tidak dan gam yang berarti pergi, jadi agama berarti tidak pergi, tetap di tempat, dan diwariskan secara turun temurun. Agama pula dapat dimaknai sebagai teks atau kitab suci, karena dapat dilihat dari setiap agama yang mempunyai kitab suci (Nata, 2011:9).

Agama Islam merupakan agama dakwah. Dakwah menjadi bagian penting dari agama Islam. Oleh karena itu, setiap muslim diharapkan mengambil peran dalam rangka pelaksanaan dakwah. Yaitu mengajak manusia kepada jalan Allah untuk memperoleh kebahagiaan di dunia dan akhirat dengan berbagai cara yang bijaksana.

Salah satu usaha untuk menambah dan memberikan pengetahuan baik itu pengetahuan yang bersifat umum ataupun yang bersifat keagamaan yaitu melalui kegiatan majelis taklim. Majelis taklim sebagai tonggak penggerak masyarakat menuju perubahan ke arah yang lebih baik lagi. Majelis taklim berperan sangat penting dalam rangka meningkatkan dan memperkokoh keimanan setiap individu masyarakat. Masyarakat diharapkan dapat memahami, menghayati, dan mengamalkan ilmu yang mereka dapatkan dari kegiatan majelis taklim.

Dalam menjaga hubungan sosial di masyarakat, kerja sama dalam komunitas bisa diwujudkan dengan memiliki sikap peduli. Kepedulian sosial merupakan sikap empati pada sesama anggota masyarakat/komunitas dalam mewujudkan minat atau kehendak kita dalam membantu orang lain. Dalam Islam sikap peduli kepada sesama sangat dianjurkan (Yosepin, 2018:124).

Dalam pelaksanaanya Majelis Taklim At-Taubah yang telah berjalan dari tahun ke tahun telah terlihat hasilnya. Itu dapat dilihat dari yang awal mulanya masyarakat kurang dalam melaksanakan perintah Allah sekarang sudah giat dalam melaksanakannya. Seperti shalat berjamaah di masjid, dan rasa kebersamaan yang semakin tinggi seperti saling membantu apabila ada warga masyarakat yang sedang kesusahan. Menurut observasi awal, sebelum diadakan majelis taklim masyarakatnya berperilaku kurang sesuai dengan ajaran Islam, masjid kosong ketika shalat berjamaah, kurangnya rasa gotong royong, dan lain sebagainya. Setelah adanya majelis taklim ada perubahan di dalam tatanan kehidupan individu maupun bermasyarakat. Mulai dari invidunya sadar akan kelalaiannya, giat melaksanakan shalat berjamaah di masjid, timbulnya rasa kebersamaan dan gotong royong, dan ada perubahan dari tingkah lakunya.

Dari hasil pengamatan yang penulis lakukan selama mengumpulkan bahanbahan untuk proses penelitian, ada beberapa skripsi yang hampir memiliki kesamaan dengan skripsi yang peneliti kerjakan, diantaranya: pertama, Peranan Majelis Taklim Mutiara dalam Meningkatkan Pemabaman Keagamaan Masyarakat di Komplek Perumaban Taman Mutiara Cibabat-Cimahi, perbedaannya dengan skripsi yang penulis kerjakan mengenai metode yang digunakan oleh da’i dalam 
pelaksanaan majelis taklim dan hasil dari majelis taklim tersebut dalam meningkatkan pemahaman keagamaan jemaahnya. Kedua, Peranan Khitobah di Majelis Taklim Matlaul Anwar dalam Pembinaan Akblak Masyarakat, penelitian ini lebih memfokuskan pada pembinaan akhlak masyarakat, berbeda dengan penelitian yang dilakukan peneliti lebih memfokuskan pada pemahaman keagamaan baik secara teori maupun secara praktek. Ketiga, Pengarub Pengajian Rutin Terbadap Peningkatan Akblak Remaja, penelitian ini hanya memfokuskan kepada peningkatan akhlak dan yang menjadi sasaran dakwahnya hanya kepada pemuda, berbeda dengan penelitian penulis yang mana sasaran dakwahnya semua kalangan dan membahas tentang Islam secara luas.

Penelitian ini dilakukan di Desa Kebonjati, Dusun Bojongjati RT 06 RW 03, Kecamatan Sumedang Utara, Kabupaten Sumedang. Dari pengamatan peneliti mengenai keadaan dan kondisi masyarakat yang heterogen ternyata memiliki visi yang sama yaitu untuk menjadi masyarakat yang agamis namun dalam pengaplikasiannya tidak sesuai dengan keadaan. Oleh karena keadaan tersebut maka tokoh agama mengadakan pengajian atau majelis taklim guna menjadikan masyarakatnya paham dengan ajaran Islam khususnya dalam kehidupan bersosial.

Fokus penelitian terhadap penelitian ini lebih kepada metode dakwah yang digunakan seorang da'i, materi yang digunakan dalam setiap menyampaikan ceramahnya, serta bagaimana perilaku mad'u dalam mengaplikasikan pemahaman keagamaan yang telah disampaikan oleh da'i dari setiap materinya. Berdasarkan latar belakang masalah yang telah disebutkan di atas, maka dapat dirumuskan beberapa pertanyaan sebagai berikut: (1) Materi apa yang disampaikan oleh da'i dalam meningkatkan pemahaman keagamaan jamaahnya? (2) Bagaimana metode dakwah yang digunakan majelis taklim At- Taubah dalam meningkatkan pemahaman keagamaan? (3) Bagaimana peranan majelis taklim At-Taubah dalam meningkatkan pemahaman keagamaan masyarakat?

Metode penelitian yang peneliti gunakan dalam penelitian ini adalah metode deskriptif kualitatif, dengan cara menganalisis hasil dari pengumpulan data yang dilakukan melalui observasi di lapangan dan wawancara dengan tokoh agama, ustadz, dan jemaah atau masyarakat khususnya yang berada di lingkungan rw 03 desa Kebonjati Sumedang.

\section{LANDASAN TEORITIS}

Teori yang dijadikan sebagai landasan dalam penelitian ini adalah teori dakwah komunikasi penyiaran Islam. Dakwah seperti yang berasal dari bahasa Arab yaitu دَعَا - يَذْعُو - دَعْوَةً yang berarti menyeru, memanggil, mengajak dan mengundang. Dakwah pada umumnya mengundang atau mengajak kepada seluruh umat manusia kepada jalan kebenaran yang sudah ada dan ditetapkan dalam AlQur'an dan hadits. 
Dakwah dalam pengertian istilah menurut Prof. Toha Yahya Oemar menyatakan bahwa dakwah Islam sebagai upaya mengajak umat dengan cara bijaksana kepada jalan yang benar sesuai dengan perintah Tuhan untuk kemaslahatan dunia dan akhirat (Saputra, 2011:1). Dari pengertian dakwah secara bahasa dan istilah, dapat dikatakan bahwa dakwah merupakan suatu ajakan kepada seluruh umat manusia kepada jalan yang benar, berbuat kebajikan serta mencegah dari kemungkaran sesuai dengan perintah Allah swt, agar mendapatkan kebahagiaan dunia dan akhirat.

Tujuan dilaksanakannya dakwah adalah mengajak manusia ke jalan Tuhan, jalan yang benar, yaitu Islam. Disamping itu dakwah juga bertujuan untuk mempengaruhi cara berpikir manusia, cara merasa, cara bersikap dan bertindak sesuai dengan prinsip-prinsip Islam (Rafiudin, 2001:25). Tujuan umum dakwah merupakan sesuatu yang hendak dicapai dalam seluruh aktifitas dakwah untuk mengajak manusia kepada jalan Allah swt.

Penelitian ini lebih terkonsentrasi kepada seberapa besar pemahaman masyarakat tentang ajaran agama Islam. Untuk mengetahui metode dakwah yang dipakai da'i dalam ceramahnya. Mengetahui materi ceramah yang disampaikan, dan mengetahui perilaku mad'u dalam pengaplikasian materi ceramah pada kehidupan sehari-hari.

Materi dakwah (maddah ad da'wah) adalah pesan-pesan dakwah Islam atau segala sesuatu yang harus disampaikan subjek kepada objek dakwah, yaitu keseluruhan ajaran Islam yang ada dalam Kitabullah maupun Sunnah Rasul-Nya. Pesan-pesan dakwah yang disampaikan kepada objek dakwah adalah pesan-pesan yang berisi ajaran Islam. Meliputi bidang akidah, syariah (ibadah dan muamalah), dan akhlak (Saputra, 2011:13).

Metode dakwah dalam Qur'an, salah satunya merujuk pada surat Al-Nahl [16]: 125, "Serulab mannusia kepada jalan Tubanmu dengan bikmah dan pelajaran yang baik dan bantablah mereka dengan cara yang baik. Sesungsubnya Tubanmu Dialah yang lebib mengetahui tentang siapa yang tersesat dari jalan-Nya. Dan Dialah yang lebih mengetabui orang-orang yang mendapat petunjuk." Merujuk pada ayat ini, terdapat tiga metode dakwah; (1) metode bi-al-hikmab; (2) metode bi-al-maw'izhah al-hasanah; dan (3) metode bi-al-mujadalab bi-al-Lati biya ahsan.

Menurut Imam al-Syaukani, hikmah adalah ucapan-ucapan yang tepat dan benar, atau menurut penafsiran hikmah adalah argumen-argumen yang kuat dan meyakinkan. Sedangkan mau'idhah hasanah adalah ucapan yang berisi nasihatnasihat yang baik dimana ia dapat bermanfaat bagi orang yang mendengarkannya, atau menurut penafsiran, mau'idhah hasanah adalah argumen-argumen yang memuaskan sehingga pihak yang mendengarkan dapat membenarkan apa yang disampaikan oleh pembawa argumen itu. Sedangkan bil mujadalah adalah berdiskusi dengan cara yang paling baik dari cara-cara 
berdiskusi yang ada (Yakub, 2000:21).

Kegiatan dakwah akan dikatakan berhasil apabila menimbulkan perubahan yang baik kepada objek dakwah. Karena apa yang diperoleh atau dihasilkan akan melahirkan respon atau efek, Jalaludin Rahmat memaparkan dengan menggunakan model komunikasi, suatu dakwah dinilai efektif manakala menimbulkan lima tanda yaitu: melahirkan pengertian, menimbulkan kesenangan, menimbulkan pengaruh pada sikap mad'u, menimbulkan hubungan yang makin baik, dan menimbulkan tindakan atau respon (Nur:2005).

Dakwah bisa dilakukan dimana saja, khususnya pada masyarakat pedesaan dakwah melalui kegiatan majelis taklim paling sering dijumpai. Majelis taklim sendiri secara bahasa berasal dari akar kata bahasa Arab, terdiri atas dua suku kata yakni majelis berarti "tempat" dan ta'lim yang berarti "mengajar". Jadi secara bahasa majelis taklim adalah sebuah lembaga pendidikan non formal yang dipandu oleh ustadz atau ustadzah, memiliki jama'ah untuk mendalami ajaran Islam serta kegiatan-kegiatan yang bermanfaat lainnya dengan tempat yang telah ditentukan (Alawiyah, 1997:1) .

Tujuan dari majelis taklim sendiri yaitu untuk meningkatkan pemahaman tentang keagamaan jemaah atau masyarakat. Pemahaman adalah tingkatan kemampuan yang mengharapkan seseorang mampu memahami arti atau konsep, situasi serta fakta yang diketahuinya. Dalam hal ini ia tidak hanya hapal secara verbalitas, tetapi memahami konsep dari masalah atau fakta yang ditanyakan, maka operasionalnya dapat membedakan, mengubah, mempersiapkan, menyajikan, mengatur, menginterpretasikan, menjelaskan, mendemonstrasikan, memberi contoh, memperkirakan, menentukan, dan mengambil keputusan (Purwanto, 1997:44). Kemampuan pemahaman tentang agama merupakan salah satu tujuan penting dalam kegaiatan proses majelis taklim, memberikan pengertian bahwa materi-materi yang disampaikan kepada jemaah bukan hanya sebatas hafalan, namun lebih dari itu dengan pemahaman jemaah dapat lebih mengerti dan dapat menafsirkan dengan sendiri tentang materi ceramah yang diterimanya.

Di dalam ranah kognitif menunjukkan tingkatan-tingkatan kemampuan yang dicapai dari yang terendah sampai yang tertinggi. Dapat dikatakan bahwa pemahaman tingkatannya lebih tinggi dari sekedar pengetahuan. Definisi pemahaman menurut Anas Sudijono adalah kemampuan seseorang untuk mengerti atau memahami sesuatu setelah sesuatu itu diketahui dan diingat. Dengan kata lain, memahami adalah mengetahui tentang sesuatu dan dapat melihatnya dari berbagai segi (Sudijono, 1996:50).

Agama Islam yang kandungan ajarannya sangat sempurna tetapi tidak berbelit-belit itu ditegakkan di atas tiga pilar utama. Dalam sebuah hadist yang diriwayatkan oleh Umar bin Khatab r.a Rasulullah Saw. diterangkan bahwa ajaran Islam memuat tiga ajaran dasar, yaitu Iman, Ikhsan, dan Islam. Ketiga 
ajaran ini pada hakekatnya merupakan satu kesatuan yang bulat dan utuh, yang tidak dapat dipisahkan satu sama lainnya (Pasha, 2003:4).

Agama merupakan sesuatu yang wajib untuk dipahami oleh seluruh umat manusia. Manusia tidak bisa hanya mengerti, mengartikan, ataupun sekedar mengetahui mana yang di bolehkan atau tidak dalam agama. Tetapi manusia juga dituntut untuk menjalankan, melaksanakan, mengikuti aturan-aturan yang ada dalam agama. Oleh karenanya diperlukan pemahaman tentang keagaamaan yang mana itu akan membawa manusia kepada jalan yang sesungguhnya, jalan yang diperintahkan Allah Swt.

Pemahaman keagamaan mengandung pengertian bahwa sampai dimana kemampuan untuk mengenali atau memahami nilai agama yang mengandung nilai-nilai leluhurnya serta mempraktikkan nilai-nilai tersebut dalam bersikap dan bertingkah laku (Kholid, 2011:24). Hal ini akan terlihat dari kemampuan seseorang untuk memahami, menghayati, serta mengaplikasikan nilai-nilai luhur agama yang dianutnya dalam kehidupan sehari-hari. Manusia menganut agama karena menurut keyakinannya agama tersebut itulah yang terbaik, karena itu ia berusaha menjadi penganut yang baik, keyakinan itu ditunjukkan dalam sikap dan tingkah laku keagamaan dan sosialnya yang mencerminkan ketaatan terhadap agamanya.

\section{HASIL DAN PEMBAHASAN}

Metode yang digunakan dalam penelitian ini adalah metode deskriptif kualitatif, yang dilakukan pada jemaah majelis taklim At-Taubah pada khususnya, dan umumnya pada masyarakat rw 03 desa Kebonjati, Sumedang. Pada awalnya majelis taklim At-Taubah didirikan dengan pengajian rutin yang dilaksanakan oleh ibu-ibu dan bapak-bapak yang bertitik fokus di tiap rumah-rumah warga. Pengajian tersebut dilaksanakan setiap dua minggu sekali, dan bertempat di rumah warga secara bergantian. Kemudian seiring dengan berjalannya waktu, pengajian tersebut diminati oleh banyak warga dan semakin bertambah jemaah yang mengikutinya.

Karena kondisi dan keadaan yang kurang memadai, maka ustadz Erfan berinisiatif untuk mengembangkan pengajian tersebut. Kemudian membentuk sebuah wadah atau sarana yang berfungsi untuk menunjang kegiatan pengajian rutin tersebut. Serta memberikan kenyamanan bagi jemaah baik tempatnya maupun kenyamanan dalam menyerap ilmu yang mereka dapatkan. Oleh karena itu, perlu adanya sebuah wadah atau sarana untuk menunjang kebutuhan warga yang haus akan kebutuhan keagamaan. Sehingga pada akhirnya dibentuklah sebuah organisasi yang bernama Majelis Taklim At-Taubah. Nama majelis taklim itu sendiri diambil dari nama masjid yang mana menjadi tempat kegiatan pengajian tersebut berlangsung. 
Dari hasil penelitian yang telah penulis lakukan di lapangan, penulis akan mendeskripsikan hasil dan temuan yang telah didapat. Kemudian penulis akan menjabarkan ragam materi yang disampaikan majelis taklim At-Taubah dalam meningkatkan pemahaman keagamaan masyarakat. Selain itu bagaimana metode yang digunakan majelis taklim At-Taubah dalam meningkatkan pemahaman keagamaan masyarakat. Kemudian yang terakhir bagaimana hasil yang didapat oleh mad'u setelah mengikuti kegiatan majelis taklim tersebut.

\section{Ragam Materi Dakwah}

Materi dakwah (maddah ad da'wah) adalah pesan-pesan dakwah Islam atau segala sesuatu yang harus disampaikan subjek kepada objek dakwah, yaitu keseluruhan ajaran Islam yang ada dalam Kitabullah maupun Sunnah Rasul-Nya. Pesan-pesan dakwah yang disampaikan kepada objek dakwah adalah pesanpesan yang berisi ajaran Islam. Meliputi bidang akidah, syariah (ibadah dan muamalah), dan akhlak (Saputra, 2011:13).

Seorang da'i dalam menentukan strategi dakwahnya sangat memerlukan pengetahuan dan kecakapan ilmu untuk memenuhi kebutuhan materi dakwahnya. Selain itu pola pikir berangkat dari pendekatan sistem, bahwa dakwah merupakan suatu sistem dan materi merupakan salah satu komponen dan unsur yang ada didalamnya. Maka materi mempunyai peranan dan kedudukan yang sejajar dengan unsur-unsur dakwah yang lainnya. Penerapan materi dakwah sangat penting karena akan menentukan proses ketika dakwah berlangsung.

Untuk menimbulkan efek kepada mad'u dengan tujuan agar mad'u dapat menyerap ilmu yang telah disampaikan, ini menjadi tugas da’i untuk mengemas materi sebaik mungkin. Pada dasarnya keseluruhan materi itu dikemas secara sederhana agar dapat membuat mad'u mudah memahami apa yang disampaikan da'i, sehingga dapat mengaplikasikannya dalam kehidupan sehari-hari.

Dalam majelis taklim At-Taubah materi yang disampaikan menyangkut masalah yang ada di masyarakat. Disesuaikan dengan keadaan dan kondisi yang sedang terjadi. Sehingga sebelum pengajian berlangsung da'i yang akan memberikan ceramahnya terlebih dahulu memilih dan memilah tema yang akan menjadi topik pembahasannya. Hal ini bertujuan agar materi yang disampaikannya itu benar-benar diperlukan dan dibutuhkan oleh sasaran dakwahnya. Materi-materi itu meliputi tentang akidah, akhlak, ibadah, dan peristiwa yang sedang berlangsung.

Materi tentang akidah disampaikan untuk menanamkan keyakinan dan keteguhan hati kepada Allah swt. Menambah keimanan dan ketakwaan bahwa segala urusan tentang kehidupan di dunia ini semuanya hanya milik Allah swt. Mengingatkan kembali bahwa apa dilakukan oleh manusia semuanya akan dipertanggungjawabkan olehnya di hadapan Allah kelak. Setiap manusia dan 
seluruh alam semesta ini semuanya akan kembali kepada pencipta-Nya.

Akidah merupakan cabang ilmu pengetahuan tentang agama dalam memahami perkara-perkara yang berkaitan dengan keyakinan terhadap Allah swt, dan sifat-sifat kesempurnaan-Nya. Keyakinan adalah mengimani dengan sepenuh hati, dengan mengucapkan kebenaran secara lisan, dan mengamalkan perintah Allah dengan perbuatan. Keyakinan terhadap akidah merupakan sesuatu yang mengharapkan hati membenarkannya, yang membuat jiwa tenang dan tentram kepada-Nya, dan menjadi kepercayaan yang bersih dari kebimbangan dan keraguan.

"Hal yang paling penting dalam setiap diri manusia yaitu menanamkan akidah. Begitu sangat pentingnya akidah karena ini menyangkut keyakinan kita sebagai manusia kepada Allah swt. Materi ini diberikan untuk menancapkan keyakinan kita bahwa seluruh alam semesta ini adalah milik-Nya, dan semua yang terjadi merupakan atas dasar kehendak-Nya. Sehingga kita dapat mengambil pelajaran dan hikmah dari apa yang terjadi." (wawancara 23 agustus 2018)

Setiap da'i yang mengisi pengajian selalu menekankan kepada mad'unya agar selalu meningkatkan ketakwaan dan keimanan kepada Allah SWT. Petuah itu selalu disampaikan manakala pengajian baru dimulai, menjadi pembuka dalam setiap ceramah yang disampaikannya. Selalu menyampaikan agar banyak shalat sunnat, khususnya shalat malam, berdzikir, bershalawat, dan berdo'a meminta pertolongan dari-Nya. Agar dapat membentengi diri dari pengaruh buruk dari perkembangan zaman yang semakin maju ini.

Fajrin menjelaskan bahwa pemaparan materi tentang akidah ini bertujuan untuk menyadarkan mad'u bahwa segala persoalan yang sedang terjadi, setiap musibah yang sedang melanda, setiap kejadian yang tidak terpikirkan oleh manusia, itu semua merupakan kehendak Allah swt. Mengingatkan bahwa Allah itu adalah hakim yang paling adil, segala musibah yang sedang dihadapi akan ada hikmah di balik semua itu. Berkeluh kesah dalam menghadapi kehidupan yang kadang tidak memihak, itu sebagain dari rencana Allah untuk hamba-Nya. Manusia sedang di uji keimanannya, dan siapa yang mampu untuk melewatinya dengan penuh keikhlasan dan ketabahan maka akan mendapatkan kemenangan dan kebahagiaan.

Materi tentang akhlak merupakan materi yang dibutuhkan dalam realitas kehidupan individu dan juga dalam berkehidupan bermasyarakat. Dalam kehidupan bermasyarakat tidak bisa terlepas dari seseorang manusia. Penciptaan manusia sebagai makhluk sosial membuatnya selalu membutuhkan orang lain. Manusia tidak bisa hidup sendiri dan bersifat individualistis dalam menjalankan kesehariannya. Setiap waktu bahkan setiap saat manusia cenderung membutuhkan keberadaan orang lain untuk memenuhi sifat sosialnya. Dalam menjalankan hidup bermasyarakat tentu bukan perkara yang mudah, menjaga 
akhlak agar tetap baik merupakan hal yang sangat penting untuk dilakukan. Akhlak yang baik akan membawa kepada rasa cinta, damai, dan tentram antar masyarakatnya. Setelah itu akan meningkatkan semangat ukhuwah islamiyah anatar umat Islam.

Akhlak merupakan penyempurna dari keimanan yang mana akan mempengaruhi pandangan hidup manusia untuk berbuat baik atau berbuat buruk. Akhlak merupakan sifat yang ada dalam diri manusia yang senantiasa tumbuh dan berkembang seiring dengan berjalannya waktu. Sifat yang mendorong untuk melakukan sesuatu tanpa mempertimbangkan segala sesuatu yang akan terjadi setelahnya. Allah Swt. telah menganugrahkan pada diri manusia suatu akal pikiran yang berfungi untuk menyaring mana yang harus dikerjakan dan mana yang harus ditinggalkan.

"Pemberian materi akhlak ini bertujuan untuk lebih meningkatkan kehidupan sosial antar warga. Mengingatkan bahwa kita itu hidup dalam lingkungan masyarakat. Dimana akan saling membutuhkan, dan menjalin kerukunan itu sangat penting. Menjaga silaturahmi dengan tetangga, tolong menolong bila ada yang membutuhkan, dan bergotong royong dalam pembangunan dengan keikhlasan." (wawancara 23 agustus 2018)

Akhlak yang baik sangat penting dimiliki oleh setiap orang. Akhlak mendorong dan memengaruhi diri untuk membentuk hati yang suci, baik lahir maupun batin yang akan berguna bagi sesama manusia ataupun makhluk yang lain. Akhlak merupakan penyempurna dari keimanan seseorang. Orang yang berakhlak mulia berarti telah mencapai tingkatan iman yang tinggi, dan akan memperoleh derajat yang terhormat di hari akhir nanti.

Penyampaian materi tentang ibadah bertujuan untuk menambah ke khusuan dalam menjalankan ibadah kepada Allah Swt. Memberikan penjelasan dan pemahaman yang tepat mengenai tata cara shalat misalkan, berwudlu, berbakti kepada orang tua, mempererat tali silaturahmi, dan yang lainnya. Hal ini supaya dalam pelaksanaan ibadahnya sesuai dengan tuntunan ajaran agama Islam. Maka dengan begitu, ibadah yang dilakukanya akan diterima oleh Allah swt.

Hakekat dari ibadah merendahkan diri kepada Allah swt dan tunduk dan patuh akan apa yang diperintahkan-Nya yang disertai dengan kecintaan kepadaNya. Kecintaan disertai ketundukan yang melekat dalam ibadah merupakan tujuan Allah dalam penciptaan manusia. Dimana dalam al-qur'an disebutkan bahwa, Allah tidak menciptakan manusia dan jin semata-mata untuk beribadah kepada-Nya. Bahkan dalam firmannya tersebut dikatakan bahwa tidak hanya manusia yang harus tunduk dan patuh dalam beribadah kepada Allah swt, melainkan bangsa jin juga diwajibkan untuk taat beribadah kepada-Nya. Hal ini menunjukkan betapa sangat pentingnya untuk beribadah, karena akan menjadi jalan dalam menghadap Sang Rabbi.

"Materi tentang ibadah merupakan materi yang disampaikan dalam majelis 
ini. Karena kita ingin memberikan pengetahuan yang luas bahwa ibadah itu bukan hanya tentang shalat, puasa, zakat saja, yang seakan-akan ibadah itu hubungan antara Allah dan hamba-Nya semata. Melainkan ibadah itu cakupannya luas, selain hablum minallah (hubungan dengan Allah), ada juga hablum minannas (hubungan dengan sesama manusia), dan hablum minal 'alam (hubungan dengan alam atau lingkungan)." (wawancara 23 agustus 2018)

Pemahaman masyarakat mengenai ibadah hanya sebatas hubungan mereka dengan Allah saja. Mereka mengartikan ibadah dengan shalat, puasa, haji, zakat, dan yang lainnya. Padahal ibadah itu luas dalam segi cakupannya. Dalam pengajian majelis taklim At-Taubah memberikan penjelasan, pemaparan tentang ibadah yang pada hakekatnya menjelaskan tentang manusia dengan penciptanya, dan manusia dengan seluruh alam semesta yang ada di dalamnnya.

Maka dengan demikian, dalam agama Islam ibadah bukan sekedar tentang shalat, puasa, zakat yang mana semua itu merupakan hubungan langsung dengan Allah dalam artian sempit, melainkan ibadah dalam artian luas mencakup semua kebaikan yang dimaksudkan dalam rangka memenuhi perintah Allah dan menjauhi segala larangan-Nya. Melaksanakan ibadah dengan niat semata-mata karena Allah swt akan menimbulkan perasaan dan hati menjadi tenang, tentram, dan damai. Semua perasaan itu akan timbul secara alami ketika jiwa dan raga itu tunduk dan patuh serendah-rendahnya dalam menghadap-Nya.

\section{Ragam Metode dakwah}

Metode dakwah dalam Qur'an, salah satunya merujuk pada surat Al-Nahl [16]: 125, "Serulah manusia kepada jalan Tuhanmu dengan hikmah dan pelajaran yang baik dan bantahlah mereka dengan cara yang baik. Sesungguhnya Tuhanmu Dialah yang lebih mengetahui tentang siapa yang tersesat dari jalan-Nya. Dan Dialah yang lebih mengetahui orang-orang yang mendapat petunjuk." Merujuk pada ayat ini, terdapat tiga metode dakwah; (1) metode bi-al-hikmah; (2) metode bi-al-maw'izhah al-hasanah; (3) metode bi-al-mujadalah bi-al-Lati hiya ahsan.

Menurut Imam al-Syaukani, hikmah adalah ucapan-ucapan yang tepat dan benar, atau menurut penafsiran hikmah adalah argumen-argumen yang kuat dan meyakinkan. Sedangkan mau'idhah hasanah adalah ucapan yang berisi nasihatnasihat yang baik dimana ia dapat bermanfaat bagi orang yang mendengarkannya, atau menurut penafsiran, mau'idhah hasanah adalah argumen-argumen yang memuaskan sehingga pihak yang mendengarkan dapat membenarkan apa yang disampaikan oleh pembawa argumen itu. Sedangkan bil mujadalah adalah berdiskusi dengan cara yang paling baik dari cara-cara berdiskusi yang ada (Yakub, 2000:21).

Adapun di perkampungan, metode ceramah masih menjadi metode yang tepat untuk digunakan. Metode ceramah yang berbentuk retorika, dengan 
merangkai kata demi kata seindah mungkin masih menjadi yang diinginkan oleh jemaah. Bagi para jamaah yang terpenting yaitu pesan yang disampaikan da'i dapat dengan mudah dimengerti, dipahami, dan diterima olehnya. Sehingga ketika jemaah meninggalkan majelis tersebut ada ilmu yang didapat dari aktivitasnya.

Dari hasil wawancara yang dilakukan dengan pihak DKM pada tanggal 22 Agustus 2018, di dalam majelis taklim At-Taubah terdapat beberapa metode yang sering digunakan dalam setiap kali ceramahnya, metode tersebut meliputi: metode bil bikmah, metode mau'izhah hasanah, dan metode mujadalah.

Pertama dakwah dengan metode bil hikmah, merupakan dakwah yang disesuaikan dengan kadar pemikiran, bahasa, dan lingkungan yang menjadi sasaran dakwahnya. Biasanya metode dakwah bil hikmah diaplikasikan kepada masyarakat yang berilmu tinggi, berwawasan luas, dan mempunyai pengetahuan yang sudah maju. Penerapan metode bil hikmah ini kebanyakan dipakai di lingkungan komplek, perkotaan, kampus, dan kelembagaan.

Tetapi tidak menutup kemungkinan metode bil hikmah ini juga dipakai dalam lingkungan pedesaan. Hal demikian dikarenakan dalam lingkungan pedesaan juga masyarakatnya bersifat heterogen. Ada masyarakat biasa yang berpendidikan sedang atau standar bahkan dibawah, dalam hal ini mempengaruhi pola pikirnya, dan ada juga masyarakat yang berpendidikan tinggi yang kesehariannya beraktifitas dalam lingkungan intelektual melalui pekerjaannya.

Dalam suatu sistem masyarakat dimana semua elemen yang ada didalamnya berbaur, dan berkedudukan yang sama, semuanya berhak disama ratakan tanpa adanya golongan kasta atau pembeda strata sosial. Maka dengan begitu, penyampaian ceramah dengan metode bil hikmah sering juga dipakai dalam pengajian yang berada di desa atau kampung, ini dikarenakan supaya semua warga berhak mendapatkan ilmu yang sama tanpa adanya perbedaan.

Quraish Shihab menjabarkan mengenai al-hikmah dalam Q.S an-Nahl:125, kata hikmah (حكمة) antara lain berarti yang paling utama dari sesuatu, baik pengetahuan maupun perbuatan. Ia adalah pengetahuan atau tindakan yang bebas dari kesalahan atau kekeliruan. Hikmah juga diartikan sebagai sesuatu yang bila digunakan/ diperhatikan akan mendatangkan kemaslahatan dan kemudahan yang besar atau lebih besar serta menghalangi terjadinya mudharat atau kesulitan yang besar atau lebih besar.

Seusai dengan penjabaran Quraish Shihab mengenai metode hikmah yang secara singkat diartikan pengetahuan atau tindakan yang jika diperhatikan atau digunakan sebaik mungkin akan mendatangkan kemudahan yang besar. Metode hikmah diperuntukkan bagi mad'u yang pengetahuannya sudah maju, agar terealisasikannya pesan dakwah yang disampaikan, materi yang disebarkan juga sesuai dengan taraf pemikiran mad'u (Quraish 2011:775). 
Kedua dakwah dengan metode mau'izhah hasanah, merupakan metode dakwah dengan tutur kata yang indah, nasehat yang baik, menyentuh jiwa, sehingga itu akan menimbulkan kesan dalam diri mad'u. Disesuaikan dengan kondisi dan keadaan mad'unya. Dakwah dengan metode mau'iz̧bah hasanah paling sering ditemukan di kampung-kampung, khususnya di masjid-masjid. Pada masyarakat yang berdomisili di kampung sendiri dakwah dengan metode mau'izhah hasanah ini akan lebih dapat diterima dengan baik dan terbuka. Itu dikarenakan pada masyarakat kampung sendiri lebih menyukai dan menimbulkan rasa senang dengan mendengarkan naehat-nasehat yang baik atau kata-kata yang indah.

Supaya dapat terealisasinya tujuan dakwah yang sesungguhnya, yaitu menimbulkan efek atau perubahan dalam diri mad'u, adakalanya seoarang da'i menyampaikan materi yang sesuai dengan kapasitas pola pikir mad'unya. Pemilihan tema yang akan menjadi materi dakwahnya, pemilihan kata yang tidak berbobot tinggi, dan cara penyampaian yang baik dan tidak membosankan.

Metode mau'izhah hasanah merupakan metode dakwah dengan nasihat yang baik. Aplikasi metode ini diperuntukkan untuk masyarakat yang awam. Yang dimaksud dengan awam disini, mereka yang memiliki ilmu namun tidak berkembang. Misal, anak-anak jalanan. Mereka adalah masyarakat awam yang hanya memiliki keterbatasan pengetahuan. Namun, metode ini juga bisa digunakan oleh da'i dengan cara personal yaitu pendekatan.

Setiap da'i memiliki kecenderungan dan kemampuan yang berbeda-beda, sehingga mempengaruhi pula terhadap cara dakwah melalui nasihat dan efek (efect) dari nasihat tersebut. Metode mau'izhah hasanah terbagi menjadi beberapa macam lagi, diantaranya; nasihat dengan kata-kata mendatar, nasihat dengan kata-kata heroik, nasihat dengan cara mengungkapkan pernyataan, metode intruksi, metode kisah, dan metode kritik (Acep, 2011:84).

Ketiga metode dakwah al-mujadalah, ini merupakan metode dakwah yang mengedepankan tukar pikiran anatara da'i dan mad'u, berdiskusi, berdebat, dan berdialog. Selain memerlukan wawasan yang luas yang harus dimiliki oleh da'i, seorang da'i juga harus pandai dan menguasai ilmu debat yang baik dan bagus. Karena dalam metode ini mad'u akan mengemukakan pendapatnya dan pandangannya mengenai apa yang menjadi pemikirannya.

Walaupun metode ini merupakan metode berdebat, mad'u bisa mengemukakan pendapat kepada da'i dengan menggunakan etika, tutur kata yang baik, sopan, dan tanpa adanya unsur kekerasan. Dengan begitu da'i akan bisa menangkap intisari dari pertanyaan mad'u dan memahaminya serta mempunyai jawaban akan persoalannya. Sehingga perdebatan itu akan menghasilkan jawaban dan titik temu tentang apa yang menjadi permasalahannya, dan akan ditemukan kejelasan serta kebenarannya, yang mana 
itu akan membuat mad'u merasa puas dengan jawaban yang dipaparkan da'i dan menerimanya dengan terbuka.

Dari ketiga metode dakwah yang telah dipaparkan tersebut. Semuanya merupakan metode yang tepat dalam kegiatan berdakwah. Masalahnya tergantung situasi dan kondisi yang dihadapi da'i dilapangan. Da'i tidak serta merta memberikan materi dengan metode yang sama ditempat yang berbeda dalam kondisi yang sama.

Dalam melaksanakan dakwah dengan menggunakan metode bil hikmah harus disesuaikan dengan kemampuan dan daya pikir mad'u. Sedangkan dalam penerapan metode mau'izhah hasanah menggunakan metode yang diperuntukkan kepada masyarakat awam, hal ini bertujuan agar mad'u tersebut dapat memahami dengan kadar keilmuannya. Kemudian yang terakhir metode bil mujadalah, metode ini digunakan da'i kepada mad'u yang sudah terbiasa berdialog, berdiskusi, dan berdebat.

Pada hakikatnya semua metode yang digunakan dalam berdakwah akan berhasil dan mencapai apa yang menjadi tujuan dakwahnya itu, jika da'i yang berperan sebagai subjek dakwah benar dan tepat dalam memilih atau mencocokan metode dakwah yang dipakai sesuai keadaan dan kondisi mad'unya. Dalam lingkungan majelis taklim At-Taubah sendiri dimana masyarakatnya yang bersifat heterogen, ketiga metode tersebut cocok dan tepat untuk digunakan. Dimana masyarakatnya pun memiliki rasa ingin tau terhadap pengetahuan dan keilmuan keagamaan yang cukup tinggi. Maka, selain mendengarkan ceramah yang dipaparkan oleh da'i, mad'u juga sering bertanya atau berdiskusi mengenai pemahaman tentang keagamaan yang kurang mereka pahami.

\section{Hasil Peranan}

Kegiatan dakwah akan dikatakan berhasil apabila menimbulkan perubahan yang baik kepada objek dakwah. Karena apa yang diperoleh atau dihasilkan akan melahirkan respon atau efek, Jalaludin Rahmat memaparkan dengan menggunakan model komunikasi, suatu dakwah dinilai efektif manakala menimbulkan lima tanda yaitu: melahirkan pengertian, menimbulkan kesenangan, menimbulkan pengaruh pada sikap mad'u, menimbulkan hubungan yang makin baik, dan menimbulkan tindakan atau respon (Nur:2005).

Majelis taklim At-Taubah turut ikut andil bagian dalam meningkatkan pemahaman keagamaan masyarakat. Pemahaman yang dimaksudkan disini bukan berarti paham secara teoritis, melainkan paham secara pengaktualisasian dalam kehidupan. Majelis taklim At-Taubah berperan sebagai wadah atau sarana untuk memenuhi kebutuhan masyarakat dalam aspek keagamaan. Aspek keagamaan yang menjadi prioritas utama untuk menanamkan keimanan dan ketaqwaan kepada Allah swt.

Majelis taklim At-Taubah sangat mengutamakan persudaraan (ukhuwah 
Islamiyah) antar warga muslim, yang bersifat; persamaan (egaliter), dan tidak memihak (non-Partisipan). Majelis taklim At-Taubah tidak memihak dan terkait pada organisasi atau partai politik manapun, berkontribusi secara postif dan proaktif terhadap kegiatan sosial kemasyarakatan demi kemashlahtan umat. Sifat persaudaraan yang selalu ditanamakan membuat masyarakat senantiasa rukun, harmonis, dan peduli terhadap satu sama lain.

Majelis taklim At-Taubah senantiasa membentuk dan mengembangkan masyarakat supaya memiliki kepribadian yang luhur, berakhlak mulia, dan beramal shaleh. Khususnya yang selalu ditanamkan kepada para pemuda yang mana akan menjadi penerus dari bangsa ini. Para pemuda yang akan berperan aktif dalam pembangunan lokal maupun nasional sebagai pengamalan ajaran agama yang diridhoi Allah Swt.

Dengan adanya majelis taklim At-Taubah masyarakat khususnya, terutama orang tua sangat antusias ingin kembali mempelajari ilmu agama walaupun usia mereka seharusnya bukan lagi ada dalam fase mempelajari. Tetapi niat dan semangat keingintahuan dalam memahami akan ajaran Islam yang begitu luas tidak menjadi penghalang untuk mencapainya.

Ketika orang lain merasa fisiknya sudah lelah dikarenakan aktifitas yang telah mereka jalani selama seharian menjadi alasan untuk berdiam diri dan beristirahat dirumah, lain halnya dengan masyarakat yang berada di wilayah majelis tersebut. Mereka tetap antusias berdatangan tidak memikirkan kelelahan yang sedang menghinggapinya. Mereka dengan khusunya mengikuti rangkaian demi rangkaian acara dalam pengajian tersebut. Bahkan sebagian ada yang membawa buku untuk mencacat materi yang disampaikan.

Kesadaran diri yang ada dalam setiap mayarakat sangat diperlukan. Karena itu akan memicu semangat mereka dalam menyelaraskan kebutuhan lahiriyah dan batiniyahnya. Ketika mereka berada dalam suatu majelis, mereka dengan seksama akan mendengarkan apa yang da'i sampaikan. Maka diharapkan ketika mad'u keluar dari majelis itu akan melahirkan efek atau respon.

Pemaparan materi yang disampaikan da'i bertujuan untuk melahirkan pengertian dalam diri mad'u. Da'i tidak bisa hanya sekedar pandai bercakap melalui perkataan indahnya. Adakalanya da'i sebelum berdakwah memperhatikan terlebih dahulu kondisi dan keadaan yang akan menjadi sasaran dakwahnya (mad'u). Pemberian materi yang berbobot tinggi tidak bisa dipakai dalam kondisi mad'u yang lingkungannya berada dalam garis menengah kebawah. Sebaliknya pemberian materi yang sederhana tidak bisa dipakai dalam kondisi dan keadaan mad'u yang berada dalam kalangan atas.

Tidak hanya materi yang harus diperhatikan da'i untuk menunjang keberhasilan dakwahnya. Metode merupakan salah satu faktor yang akan menentukan keberhasilan dakwahnya. Materi dan metode merupakan dua sisi 
yang tidak dapat dipisahkan, keduanya harus selalu berdampingan. Pemaparan materi dengan metode yang tepat akan melahirkan pengertian bagi setiap mad'u.

Ibu Risma yang merupakan jemaah aktif menuturkan, setiap minggunya materi yang disampaikan da'i berbeda-beda, dan itu membuat ilmu keagamaannya semakin betambah. Selain itu setelah da’i selesai memberikan ceramahnya, dibuka sesi tanya jawab, atau sekedar berdiskusi mengenai ceramah yang telah disampaikan. Hal itu sangat bagus karena bisa memberikan pengertian yang lebih mendalam untuk memahaminya.

Menimbulkan kesenangan pada mad'u merupakan cara yang ampuh untuk membuat mad'u tidak merasa bosan. Kesenangan bisa ditimbulkan karena seorang da'i menyampaikan ceramahnya dengan pembawaan yang santai, tidak terlalu serius, yang mana akan menimbulkan ketegangan. Selain itu pembawaan da'i yang memasukkan unsur humor menjadi hal yang dinikmati oleh mad'u. Walaupun terkadang pembawaan seorang da'i humoristis, da'i tetap pada tujuannya yakni menyampaikan ilmu yang bermanfaat untuk kemaslahatan umat.

"Saya menikmati setiap apa yang disampaikan da'i, saya merasa puas dengan ilmu yang diberikan olehnya. Senang selama mengikuti pengajian ini, karena selain mendapatkan ilmu, disini juga bisa bersilaturahmi dengan jamaah yang lainnya." (wawancara 24 Agustus 2018)

Mad'u merasakan kesenangan dalam menerima pesan dakwah, karena mad'u juga bisa bertanya tentang segala permasalahan yang bahkan diluat konteks materi dakwah. Bahkan terkadang timbul perdebatan antara da'i dan mad'u, tetapi itu dilakukan dengan etika yang semestinya, yang mana tidak menyinggung perasaan satu sama lain. Da’i menyampaikan materinya juga dengan perasaan yang senang, ramah tamah, selalu tersenyum, dan itu akan menimbulkan kesenangan dalam masing-masing diri mad'u.

Salah satu tujuan dari dakwah untuk menimbulkan pengaruh dalam diri mad'u. Dalam artian menimbulkan pengaruh yang semakin baik dari sikap sebelumnya. Mulai dari lebih menghargai waktunya, memanfaatkan waktu dengan bijak, berbicara dengan tutur kata yang baik dan sopan, mengingatkan satu sama lain bila ada kesalahan, saling menolong, dan ajak-mengajak dalam hal kebaikan. Salah satu hal yang paling menonjol adalah selalu memakmurkan masjid shalat berjamaah ketika adzan sudah berkumandang.

"Intinya yang pertama lebih kepada kesadaran diri sendiri. Ada perubahan sikap yang dirasakan stelah mengikuti pengajian ini. Misalnya saja, kalau adzan berkumandang segera bergegas ke masjid. Begitupun yang saya terapkan kepada anak-anak saya, kalau sudah adzan yang lelaki segera ke masjid dan yang perempuan saya ingatkan agar shalat tepat waktu." (wawancara pada tanggal 23 Agustus 2018)

Seperti yang telah dijelaskan, dalam pengajian majelis taklim At-taubah tidak hanya membahas mengenai akhlak saja, melainkan tentang ibadah dan juga 
akidah. Pembentukan karakter yang akan terlihat dalam kehidupan bermasyarakat sangat menjadi perhatian. Karena karakter akan menentukan pandangan orang terhadap apa yang dilihatnya.

Hubungan yang semakin baik tidak hanya timbul antara mad'u dengan mad'u saja, namun hubungan seperti itu juga harus ditimbulkan antara mad'u dengan da'inya. Karena ini merupakan salah satu pencapaian dari kegiatan dakwah. Menimbulkan hubungan yang harmonis antar semua elemen yang ada dalam tatarannya.

Aktivitas dakwah dengan perubahan-perubahan yang baik akan melahirkan hubungan antar mad'u menjadi baik pula. Dengan selalu menjaga ucapan, menghargai satu sama lain, tidak menyinggung atau menyakiti hati siapapun itu menunjukkan interaksi yang baik dan manjalin hubungan yang baik antara mad'u dan da'inya.

"Kita selalu diingatkan agar senantiasa untuk menjaga tali silaturahmi supaya tidak putus. Karena Allah tidak menyukai orang-orang yang memutuskan tali silaturahmi. Ketika saya malakukan kesalahan baik itu melalui perbuatan atau perkataan yang tidak berkenan di hati orang lain, saya lebih baik mengalah dan meminta maaf duluan daripada nantinya timbul perselisihan dikarenakan samasama keras kepala. Yang paling penting itu selalu menjaga keharmonisan antar warga. (wawancara 24 Agustus 2018)

Ibu Atin selaku jemaah pengajian majelis taklim At-Taubah memaparkan, pengajian ini memberikan kesadaran baginya tersendiri untuk selalu menjaga hubungan yang baik dengan anggota keluarganya, dengan tetangganya, ataupun dengan warga yang lainnya. Karena hidup bersosial itu dimulai dengan hal yang sederhana. Bagaimana kita dapat mengerti dan memahami orang-orang yang berada disekitar kita. Menumbuhkan rasa peduli, percaya, dan menghargai akan menimbulkan hubungan yang semakin baik dalam kehidupan sosial bermasyarakat.

Tindakan atau respon yang ditunjukkan oleh mad'u dapat dilihat dari perubahan sikapnya, apakah sikap itu semakin baik atau malah sebaliknya, semakin buruk. Jika semakin baik, maka da'i telah berhasil dalam pelaksaan dakwahnya. Karena mad'u mengerti dan memahami lalu melaksanakan apa yang telah disampaikan da'i tersebut. Adapun kalau terlihat semakin buruk maka da’i harus mencari cara kembali untuk merubahnya ke keadaan yang baik dan semakin baik.

Dari empat poin yang telah dipaparkan sebelumnya, dari mulai melahirkan pengertian dan yang terakhir yang menjadi target utama dari aktifitas dakwah yaitu menimbulkan tindakan atau respon. Tindakan atau respon yang dimaksudkan bukan sekedar untuk mad'u saja, tetapi juga harus terjadi dalam diri da'inya. Tindakan atau respon dapat terlihat dari kehidupan kesehariannya, dan 
ini memerlukan waktu yang berkala. Tindakan atau respon ini merupakan tujuan utama dalam kegiatan berdakwah, yaitu menimbulkan perubahan. Perubahan yang dimaksudkan merupakan perubahan yang asalnya buruk menjadi baik, dan yang asalnya baik menjadi semakin baik.

\section{PENUTUP}

Berdasarkan penelitian melalui pendekatan studi deskriptif kualitatif terhadap peranan majelis taklim dalam meningkatkan pemahaman keagamaan masyarakat, yang mana penelitian ini bertujuan untuk mengetahui materi yang disampaikan, metode yang digunakan, dan hasil dari peranan majelis taklim itu dalam meningkatkan pemahaman keagamaan masyarakatnya. Maka dapat diambil kesimpulan sebagai berikut:

Pertama, materi yang disampaikan oleh da'i dalam pengajian mejelis taklim At-Taubah merupakan materi yang sederhana, yang tidak berbobot tinggi karena disesuaikan dengan kondisi objek dakwahnya. Pemilihan materi merupakan sesuatu yang penting untuk menunjang kegiatan dakwah agar pesan yang disampaikan da'i dapat diterima dan dipahami oleh mad'u. Dengan melihat dari kondisi dan keadaan objek disekitaran majelis taklim dari segi perekenomian dan pendidikan yang dapat dikatakan menengah kebawah, materi yang disampaikan oleh da'i meliputi akidah, akhlak, ibadah dan keadaan sosial masyarakat yang sedang terjadi.

Kedua, metode merupakan cara yang dilakukan oleh seseorang untuk mencapai tujuan yang diinginkan. Dalam aktivitas dakwah metode merupakan salah satu unsur yang tidak boleh ditinggalkan. Metode untuk menyampaikan dakwah sangat variatif, pemilihan metode digunakan sesuai dengan karakteristik dan klasifikasi yang akan menjadi sasaran dakwah. Itu diperlukan supaya mad'u dapat menerima dan memahami sehinga dapat mengaplikasikan apa yang disampaikan oleh da'i. Dalam majelis taklim At-Taubah sendiri metode yang digunakan mengacu pada QS. an-Nahl: 125 yang menjelaskan tentang tiga metode dakwah, meliputi: metode dakwah bil hikmah, metode dakwah bil mau'idzatil hasanah dan metode dakwah bil mujadalah.

Ketiga, majelis taklim At-Taubah turut ikut andil bagian dalam meningkatkan pemahaman keagamaan masyarakat. Majelis taklim At-Taubah berperan sebagai wadah atau sarana untuk memenuhi kebutuhan masyarakat dalam aspek keagamaan. Aspek keagamaan yang menjadi prioritas utama untuk menanamkan keimanan dan ketaqwaan kepada Allah swt. Dalam pelaksanaanya, majelis taklim At-Taubah telah memberikan dampak perubahan dalam tatanan sosial masyarakatnya, dan yang bersifat invidu, baik dari segi peningkatan kualitas keimanannya, maupun jiwa sosialnya.

Dari uraian diatas dapat diambil kesimpulan yaitu dalam pelaksanaan kegiatan dakwah yang diprakarsai oleh majelis taklim At-Taubah menyampaikan 
materi tentang akidah, akhlak, ibadah dan keadaan sosial masyarakat yang sedang terjadi. Metode dakwah yang digunakan mengacu kepada Surat An-Nahl: 125, yang membahas tentang metode dakwah bil hikmah, metode dakwah bil mau'idratil hasanah dan metode dakwah bil mujadalah. Hasil dari pelaksanaan kegiatan majelis taklim tersebut dapat disimpulkan bahwa pengajian tersebut memberikan efek, dan mendapatkan respon yang positif dari jemaahnya. Hal itu terlihat dari hasil observasi dan wawancara yang telah penulis lakukan.

Adapun saran yang ingin penulis sampaikan dalam penulisan karya ilmiah ini diantaranya: Pertama, dalam pelaksanaannya pengajian yang diprakarsai oleh majelis taklim At-Taubah lebih ditingkatkan lagi kualitasnya. Kurangnya da'i yang memberikan ceramah dalam pengajian tersebut bisa dicari solusi untuk menambahnya supaya proses penyampaian pesannya dapat lebih variatif. Kedua, mencoba dengan memakai media baru yang jarang ditemukan dalam pengajianpengajian yang dilaksanakan di kampung-kampung. Seperti, dengan memakai infokus, yang bisa menjelaskan dengan media gambar atau audio visual, membuat bulletin, sehingga mad'u tidak hanya mendapat tambahan ilmu melalui ceramah saja, tetapi ada teks tertulis yang bisa di baca dimana saja, khususnya dirumah.

\section{DAFTAR PUSTAKA}

Alawiyah, T. (1997). Strategi Dakwah di Lingkungan Majelis Taklim, Bandung: Mizan.

Aripudin, A. (2011). Pengembangan Metode Dakwah, Jakarta: PT Raja Grafindo Persada.

Enjang, \& A. (2009). Dasar-dasar Ilmu Dakwah, Bandung: Widya Padjajaran.

Haeni, N. (2005). Penerapan Teknik Khitabah Pada Pengajian Harian di Masjid AlHidayah Dampaknya Terhadap Akhlak Pemuda Desa Margahayu Utara Bandung. Skripsi, Jurusan Komunikasi dan Penyiaran Islam, UIN Sunan Gunung Djati, Bandung.

Kholid, A. (2011). Agama (Kultural) Masyarakat Pinggiran, UIN-Maliki Press

Munir, M. (2003). Metode Dakwah, Jakarta: Kencana Prenada Media Group.

Nata, A. (2011). Metodologi Studi Islam, Jakarta: Rajawali Pers.

Nottingham, E. K. (1996). Agama dan Masyarakat Suatu Pengantar Sosiologi Agama, Jakarta: PT Raja Grapindo Persada.

Pasha, M. K. (2003). Akidah Islam, Yogjakarta: Citra Karsa Mandiri

Purwanto, N. (1997). Prinsip-Prinsip dan Teknik Evaluasi Pengajaran, Bandung: PT. Remaja Rosdakarya

Rafiudin dan Maman A. J. (2001). Prinsip dan Strategi Dakwah, Bandung: Pustaka Setia 
S. Lukman, Y. Z. Abidin, A. Shodiqin

Saputra, W. (2011). Pengantar Ilmu Dakwah, Jakarta: PT Rajagrafindo Persada

Shihab, M. Q. (2011). Tafsir Al-Mishbah, Pesan, Kesan dan Keserasian al-Qur'an, Jakarta: Lentera Hati.

Sudijono, A. (1996). Pengantar Evaluasi Pendidikan, Jakarta: PT. Rajagrafindo Persada

Yakub, A. M. (2000). Sejarah dan Metode Dakwah Nabi, Pejaten Barat: Pustaka Firdaus

Yosepin, P. (2018). Revitalisasi Masjid Melalui Kepedulian Sosial Lembaga Takmir Masjid Nahdatul 'Ulama (LTM NU) Terhadap Komunitas Pengemudi. dalam Ilmu Dakwah: Academic Journal for Homiletic Studies. 12(1) 124 